\title{
THE KOREAN UNIFICATION: TRAPS AND CHALLENGES
}

\author{
Ed. by \\ V. Mikheev, \\ A. Fedorovsky
}


УДК 327(519)

ББК 66.4(5Коо)(5Кор)

Kor 75

Series "Library of the Primakov Institute of World Economy and International Relations"

Reviewer:

Voitolovskii F.G., Doctor of Political Sciences, Professor

Editors:

Mikheev V.V., Doctor of Economics, Fedorovsky A.N., Doctor of Economics

Kor 75

The Korean Unification: Traps and Challenges / Mikheev V., Fedorovsky A., eds. Moscow, IMEMO, 2016. -28 p.

ISBN 978-5-9535-0465-2

DOI:10.20542/978-5-9535-0465-2

The study of possible risks and traps of future unification of Korea. Consequences of transformation of North Korean political system. Problems related to maintaining law and order, legal system and justice during the transition period. Analysis of possible traps related to structural and economic reforms (legalization of "grey economy", etc.). Main social and economic risks connected with reform and reorganization of military industry, as well as keeping unemployment and migration under control. Security and diplomatic risks in economic and political relations between Korea and regional powers during unification.

To view IMEMO publications, please visit our website at http://www.imemo.ru

ISBN 978-5-9535-0465-2

(C) IMEMO, 2016 


\section{Contents}

Introduction Ошибка! Закладка не определена.

I. Probable scenarios of unification.................................................. 6

II. Political system. What to do with the Workers' Party of Korea ... 9

III. Providing legal order and security. Judicial system.................... 11

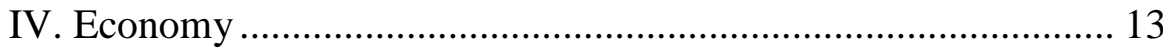

V. Foreign and defense policy: relations with China, USA, Japan

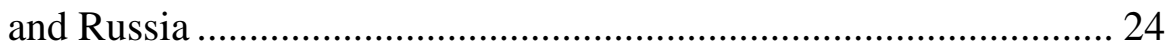

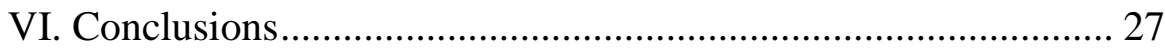




\section{Introduction}

This paper is prepared at the Center of Asia-Pacific Studies of the Primakov National Research Institute of World Economy and International Relations (IMEMO) as part of the research project "The Korean Unification: Traps and Challenges", supported by the Korea Foundation (Republic of Korea). Key authors and editor-in-chiefs of this research report are Prof. Vasily Mikheyev, a corresponding member of the Russian Academy of Sciences, and Prof. Alexander Fedorovsky. Also, Evgeniya Klyueva, Vitaly Shvydko and Kristina Voda contributed to compiling the report and preparing the manuscript for publication.

When assessing the prospects for Korean unification, politicians and experts usually take into account political, cultural, humanitarian benefits, which will hopefully be brought about to the Korean people by the unification. Also, economic cost of the long process of mutual adaptation of two Korean states are analyzed, first of all expenses which will have to be covered by allocations from the South Korean state budget for many years until the funds invested into the North begin to bring return.

At the same time, financial burden is certainly not the only problem related to unification. Many other aspects of Korean unification have caught experts' attention. Particularly, studies conducted by the Korean Institute of National Unification need to be mentioned in this regard. In this paper authors review the set of risks, challenges and traps on the way to unification which are partly evident now, while others are latent and will fully reveal themselves during the unification process, putting at risk its implementation and final results.

During the 70 years that have passed since the division of the country the views on possible ways of Korean unification underwent considerable changes.

In the second half of 1940's after the end of World War II the possibility of reunification depended on the interests of the USSR and the USA which exercised administrative control over the northern and southern parts of Korea before the Republic of Korea (ROK) and the Democratic People's Republic of Korea (DPRK) were established. The main challenge at that time was to reconcile interests of the former USSR and the USA to keep Korea united. Just like in the case of Germany, it proved to be impossible. 
In early 1950's North Korea unsuccessfully tried to carry out forceful integration of the South based on North Korean communist model. The South also failed to use the situation after the retreat of North Korean army to the Chinese border for the unification of the country based on South Korean political model. The crucial role here again was played by the USSR and the USA, which preferred to preserve military and political status quo on the Korean peninsula not to risk nuclear war. Thereby a compromise answer was given to the strategic dilemma of including united Korea into one of the two large "camps" - "socialist" or capitalist.

From 1960's to mid-1970's North Korea kept advantage over South in economic competition between the socialist North and the capitalist South. It allowed Pyongyang to declare "the principles of peaceful unification", playing on psychological heartstrings of the divided nation and covertly preparing a trap for the South, being completely sure of being able to extend its own political and economic system to entire Korean peninsula in case of unification.

From mid-1970's, after "Hangana miracle", advantage in performance of economies of the two parts of the peninsula began shifting toward South. First Pyongyang made an attempt to use military force again relying on support by (then Maoist) China. However, Beijing leaders rejected the idea of a new war. They forced Pyongyang to revise the concept of unification. Its main goal changed from "communist" absorption of the South to the survival of the North Korean regime in its antagonism with South Korea, which was gaining economic, technological and social advantage.

The North Korean concept of the North-South Confederation that was put forward in 1980 envisaged not seizure of the southern part of the peninsula by the North, but preservation of North Korean socialist model in the framework of the united Korean state.

From the point of view of interests of the Republic of Korea, the main trap of such an option would have been the preservation of Kim Il Sung's regime and its permanent pressure upon the authorities of the South to pump out economic help, as well as continued threat to the security of South Korean political regime which would still have been regarded by the North as hostile.

After the collapse of the USSR in 1990s and 2000s Kim Jong Il's regime, having faced consequences of the economic crisis caused to a 
considerable degree by the suspension of Soviet aid de facto dropped the issue of unification while keeping this traditional slogan intact in its official propaganda.

Today Pyongyang really understands that unification would mean the victory of South Korean much more efficient economic and political model and, respectively, abolition of the 70 years-long rule by the Kim clan in the North.

In these conditions, the main trap for the South is the temptation to believe (in spite of the fact that there is absolutely no ground for that) that there is a possiblility to unify Korea on a basis other than market democratic model now practiced in the South.

In this paper authors analyze only those challenges and traps which could arise in the only realistic option of Korean unification, which they believe to be the unification on the basis of South Korean democratic system and market economy.

Though social problems are the most dangerous trap standing in the way of unification, this report has no special section that would deal with them. In this paper authors analyze social aspects of the Korean unification through a prism of economic and political problems.

\section{Probable scenarios of unification}

As noted above, the only acceptable option of unification, from our point of view, is the integration of the two parts of the Korean Peninsular on the basis of the system of market democracy, the rule of law and basic democratic values, including individual rights and freedoms.

Any other scenarios suggesting preservation of North Korean regime in unified Korea in the form of Confederation or in any other form contain strategic traps, disastrous for prospects of creating the united Korea.

First, conservation of current North Korean regime and acceptance of the political independence of the North in the framework of Confederation does not remove existing nuclear, military, political, ideological and other threats to security of the Korean Peninsula and neighboring countries. Moreover, Pyongyang will have additional 
opportunities to escalate tensions, using financial flows from the South which will be unavoidable for understandable reasons, if only to show that unification did occur and rich South now must help poor North.

Secondly, in case of full integration of present North Korean political elite into South Korean democratic system other dangerous scenarios are possible, though they may look impossible at first glance. For example, North Korean voters who will account for more than $30 \%$ of total electorate, may vote collectively and "in the right manner" in North Korean tradition thus giving the Workers' Party of Korea (WPK) a majority in the united Korea's parliament. One more option of manipulation with "rules of the game" in a "manageable democracy" in the North would be securing $30 \%$ of voices that would allow Kim Jong Un to win against several South Korean candidates at presidential elections.

Evident absurdity of such traps once again emphasizes the fact that the only realistic option of unification involves transformation of political and economic system in the North in line with South Korean model.

However, this option, being the only realistic one, still contains several risks considered below.

Two main scenarios of the unification of Korea on "Southern", i.e. on democratic market basis are possible.

The first one is that of a very fast ("instant") unification. Challenges and risks of this scenario stem from high probability of social chaos arising immediately after such landslide unification. The latter would imply full paralysis of administrative control in the North, failure of the minimum necessary infrastructure to secure the operation of manufacturing enterprises, mass inflow to the South of North Korean citizens absolutely unprepared to start a new life under capitalism; attempt of large-scale spontaneous emigration to China and Russia aggravating political tension around the Korean Peninsula.

The second scenario envisages temporary coexistence of the two Korean states developing on shared principles of market economy, openness and democracy. Advantage of this scenario is that citizens in the North will first "learn how to catch fish" in the conditions of a market economy, i.e. learn basic principles of market system, information transparency, democratic freedoms, and reunite with the South after achieving mature knowledge of all these things. 
At the same time, this scenario also contains strategic traps. Process of "training", especially learning freedom and openness, can be not as smooth and successful as optimists believe, especially if we take into account that local understanding of democracy in the North may well bear the impact of the previous system and lead to revival of totalitarianism in a new form. As a result, in the political sphere there will be mere "façade change" with some personal changes while preserving absolute control by established power groups in Pyongyang and in the regions. Thus instead of creation of a market economy we will see the consolidation of "crony capitalism" - a quasi-market criminal system based on corruption as a heir to underground economy of the present-day DPRK.

In the end, there is a high risk of new leaders with their roots deep in present-day North Korea will politically survive and retain their control in the process of Korea's unification. The nuclear problem will not be resolved, and the new regime in the North will still be aggressive and posing threat to South Korea and neighboring countries. Pyongyang propaganda may succeed in gradually convincing people in the North that the responsibility for the new challenges rests wholly with the leaders of the South. Such an argument which will benefit North Korea's "nomenclature" may prove to be very effective.

Evidently, to avoid the above-described traps the South will be compelled to opt for slow stage-by-stage unification process involving some rigid administrative restrictions and mechanisms, including temporary maintenance of barriers dividing the united Korea. The task would be first to help Koreans from the North to master basics of legal market economy, culture of resolving issues using legal system, and then give them the opportunity to fully integrate themselves into political and economic system of the united Korea, including the freedom to reside in any part of the country. Following a detailed road map of reforms will help avoid a loss of control over the speed and content of reforms.

Risks of this option relate to the probability of growing discontent among people in the North who will not get expected instant access to benefits of the South. There is also a risk that groups dissatisfied with the situation will become active in the South, especially among the left-wing political forces and representatives of non-governmental organizations that would insist on fast and unconditional extension of basic democratic rights and freedoms, including the freedom of migration, to residents of the North. 
However, these risks can be mitigated by a rational policy of the South carrying out gradual modernization of the North Korean economy with different sectors and regions exposed to modernization step by step. That would also require targeted explanations of terms and conditions of full unification; developing training and educational programs for those willing to quickly move over to the South; granting financial support to those continuing to live in the North, etc.

\section{Political system. What to do with the Workers' Party of Korea}

The main challenges of the initial stage of the process of unification are linked to the solution of a fundamental task: how to transform present totalitarian political system of North Korea and what to do with the WPK, which is not simply a ruling party, but a tool to organize life of North Korean society and to exercise administrative and political control over it. Thus it is necessary to take into account that in present-day North Korea any person holding managerial or expert's position is a member of ruling party, irrespective of his or her profession and occupation.

Experience of Russia and other countries of Eastern Europe shows that ruling communist parties finally were banned or reorganized. Instead, new parties mostly of social democratic nature were set up. Discredited former leaders of communist parties were compelled to leave political scene (Russia, Czechoslovakia) or brought to justice with applicable articles of the Criminal Code (East Germany). At the same time leadership of newly established parties often consisted of not only those who had been in opposition to former rulers, but also of members of the 2nd and 3rd tier of the former ruling party "nomenclature". Moreover, in some former communist countries, like in Lithuania and Bulgaria, new parties were led by the former ruling party leaders who rejected communist ideology and converted themselves into proponents of market and democracy.

Against this background, one can learn from the collapse of totalitarian regime in Romania. While long-time dictator N. Ceausescu was executed, another leader of Romanian Communist Party (I. Iliescu) managed to win elections and lead the country as democratically elected 
president. This example is especially instructive if we consider the fact that at the time of collapse the communist regime in Romania was the most cruel dictatorship of all regimes of Eastern Europe.

In Russia, the Communist Party of the Russian Federation (CPRF) was established, but its leaders generally consisted of people from medium and lower layers of the former nomenclature of the Communist Party of the Soviet Union. They were people incapable to adapt to new political and economic conditions. At the same time major part of former capable party staff, top managers of enterprises and authorities in Moscow and the provinces succeeded in getting access to sizable pieces of public property even before formal collapse of the USSR and the start of market reforms.

There are also China and Vietnam - «socialist» countries in which ruling communist parties proved capable to lead transformation to market economy and opening to the outside world.

In North Korea the ruling WPK does not reveal ideological and political potential to lead reforms, taking example from China and Vietnam to regularly change political leaders in the country and secure selfrejuvenation of elites. The ruling Kim clan have not shown readiness to make fundamental reforms, still seeing main threats to its stability not inside the country but outside of it. With political system rapidly decomposing, attempts to selectively ease restrictions in economy despite continuing repressions (and, perhaps, under their influence) result in complete loss of control over actual developments.

As civil and military functionaries are increasingly involved in commercial operations, leaders of North Korea become more and more alienated from North Korean diverse elite groups. Proclaimed political goals deflate, legitimacy of party and state authority is weakening and administrative mechanisms are degrading.

In the conditions of systemic collapse, the option of banning the WPK and setting new parties will be most appropriate. It is the most convenient option for those WPK functionaries who are ready to change in the direction of market economy and democracy, but want to have "a free hand" and not be constrained by former leaders who enjoyed absolute power in the country in reality as well as in the perception of the population.

One more lesson of collapse of world communism is a possibility to use the phenomena of puppet political parties. In East Germany following a 
ban on the Socialist United Party of Germany, these parties formed the first post-communist government, which ruled the country for a year until the unification with West Germany.

In North Korea there is an opportunity to involve into the transition process two puppet parties now completely under control of the WPK - the Buddhist Chondoist Chongu Party (Ch'ŏndogyo Ch'ŏngudang) and the Korean Social Democratic Party.

With political and financial support from the South Korean authorities, these parties could attract sympathy of the part of the population during the period when new political parties will be established after disbanding the WPK. For example, Chondoist Chongu Party, like Komeito party in Japan, can play the role of a defender of traditional values and the principles of mutual aid, getting itself involved in supporting the needy by distributing products, clothes and medicines. The Social Democratic Party may look attractive to North Korean intellectuals.

\section{Providing legal order and security. Judicial system}

Collapse of communist system gave birth to different scenarios and ways of maintaining internal security and law and order. In some countries (like Russia) new security services, police, courts, etc. generally were staffed by officers and employees who held similar positions in communist times. In others (Baltic States, Eastern Europe) police force basically retained its former staff, whereas security service, prosecutor's offices and courts underwent deep reforms.

Practically in all these countries legal system was radically revised, and new Constitutions guaranteeing basic human rights adopted. Legal system was re-established to enable functioning of market mechanisms and protect private property. On the other hand, laws protecting exclusive rights of communist parties were cancelled.

At the same time, transition to capitalist way of life and removal of pressures of authoritarian power in all post-Soviet countries were accompanied by growing criminality, including the spread of corruption. 
Similar traps await reformers in North Korea. First of all, it is a risk of large-scale spread of criminal organizations, including gangs of racketeers and criminal groups controlling not only small, but also big business; transformations of corruption into an all-embracing form of organization of new private business on the root level.

In this regard, in case of North Korea preventive reforming of lawenforcement and legislative system would be advisable. The system of law and order existing in present-day North Korea should be totally demolished and replaced by South Korean systems and practices. Politically, it will hardly cause protests from North Korean elite, which is ready to enter the process of unification and starting legal businesses.

Traps are linked to police and judicial system staff, with the latter being the greatest problem. There can be a temptation to dispatch to the North investigators, prosecutors, judges and lawyers from the South. In this case, danger of protest may be real with the North seemingly being the victim of the South's justice.

Obviously, creation of new judicial system staffed by new people selected and trained for that mission would be a good solution. Nevertheless, formation of such new system exclusively by the South could look as if the South is creating a repressive system in its own interests. In this regard, two important aspects able to lower risks of public misunderstanding should be noted. First, training of lawyers and legal reform could be exercised by experts from authoritative international organizations such as the UN and its specialized organizations, which could also provide part or the whole of necessary funding. Second, residents of the North could be engaged in creating the system of justice there in some capacity (for example, as jurors). Educational TV programs may also play an important role in educating the population of the North.

Anyway, it would be necessary to control execution of justice appropriately by new criminal and civil courts. For that, transparency of doing justice should be maintained, with mass media possibly used for that purpose.

One more trap is the treatment of political prisoners. These people will need special programs to adapt them to new rules and living conditions in the united Korea. 
A special problem that needs new legal framework is the problem of North Korean refugees. Their expected flow to the South will require new legal instruments to maintain friendly relations between South Koreans and people in the North who will put social pressure upon the South. An inadequate solution to this problem will create serious challenges to social stability on territories to the North of the 38th parallel.

To ease the situation, as well as many other negative aspects of economic transformation in North Korea, prolonged existence of two Korean states at the initial stage of unification would be the most rational option. It could last until the North learns to some extent how "to catch fish with the presented rod" in a market economy, rather than simply "eat the supplied fish".

It is necessary to see clearly that the point is a fundamental transformation of all economic, social and political ways of life of North Korean society, not some mystical transit of North Korean realities into South Korean way of life.

The option of having two separate market economies on the Korean Peninsula at the initial stage of modernization of the North would help to avoid putting huge social, psychological and financial burden on Seoul's back by avoiding mass migration to the South of residents of the North, unprepared for living in South Korea. A rise in the number of work migrants (from present 50000 to may be 500 000, including those working in the Russian Far East) can become a partial solution of social problems and a means to boost income of North Korean households, if North Korean workers are granted the right to freely dispose their earnings.

\section{Economy}

Currently official North Korean economy is almost completely incapacitated, except for sectors linked to nuclear and missile technologies. Sectors burdened with big problems include large-scale and small enterprises of heavy and light industry, and also suppliers of services distributed on non-commercial (non-market) basis.

Kim Jong Un's administration tries to reinvigorate local economy, partly by allowing peasants to use part of agricultural land to cultivate 
products to sell on free markets ("family contract" system since 2013). Some industrial enterprises also get a right to dispose part of their produce at their own discretion. Similar practice was to some extent used in the countries of Eastern Europe and the USSR. However, it could not help to overcome fundamental problems of command-type planned economy.

\section{(i) "Gray economy" and black market economy}

Now semi-legal and illegal ("gray" and underground) commercial activity forms the basis of current business activity in the North. Main features of such practices are determined by the fact that certain North Korean citizens (executives; WPK, civil or military bureaucracy) use assets under their control (facilities, vehicles, construction equipment, opportunities to engage in foreign trade operations, etc.) in their own interests. The state officially does not consider such activities to be legal, but does not prevent them from being waged, reserving for itself the right to make opportunistic decisions depending on concrete situation.

The main spheres of North Korean "shadow" economy are:

$\checkmark$ agriculture and fishery;

$\checkmark$ trade;

$\checkmark$ transport;

$\checkmark$ services sector;

$\checkmark$ construction and renovation works;

$\checkmark$ illegal (involving unauthorized use of raw materials) production of consumer goods;

$\checkmark$ production and export of some types of mineral raw materials;

$\checkmark$ commercial deals with foreign partners;

$\checkmark \quad$ usury, illegal banking and foreign currency transactions.

Such activities ensure survival of part of the North Korean population whereas most of citizens of North Korea live on the verge of starvation. 
According to our estimates, about $50 \%$ of the population of North Korea are engaged in some way in illegal economy. However, the number of those succeeding in it amounts to no more than 10-15\%. These figures are estimates based on indirect evidence, such as the number of clients of cell phone operators.

\section{(ii) Military industry and problems of employment}

Transition of North Korea to market mechanisms will aggravate situation in the main sector of North Korean economy - military production and related industries, such as heavy industry.

In the Soviet Union before its collapse up to $70 \%$ of all manufacturing enterprises were directly or indirectly engaged in military production. Russian experience shows that conversion from military to nonmilitary production, i.e. transfer of military enterprises to production of consumer and investment goods, requires input of large amounts of capital and considerable time. Full conversion is impossible without large-scale financing for prolonged time, if those enterprises are to achieve the required range and quality of products.

Suspension of production by Russian defense industry enterprises and their contractors had negative impact on general economic and social situation in the country and raised negative attitude to market reforms in broad sections of the public. Social stability could deteriorate to the point of disaster if masses of people losing their jobs with no means to support their lives come out on the streets.

In Russia, measures which prevented irreversible negative consequences were taken at regional and company level. Part-time employment became general practice. Formally, workers were not laid off and even received small allowances. From time to time they were called in to fulfill occasional orders for extra fee. At the same time, they were allowed to look for opportunities of self-employment, which played a certain positive role in Russia during transition to market economy when many industrial enterprises and public institutions were closed or scaled down. 
People got new employment at operating enterprises or started looking for new sources of income (production of foodstuffs on their own plots of land and at dachas, renderin small services, private taxi services, seasonal employment as hired hands in agriculture and construction, etc.) . That made it possible for people to avoid or alleviate psychological stresses and gradually adapt to the conditions of market economy.

Considering that the share of urban population and the structure of economy in North Korea are close to those of the Soviet Union in 1980's, Russian experience of adapting heavy defense industry to market economy can be applied to North Korea. Ignoring social problems resulting from suspending production and modernizing defense and heavy industry can aggravate difficulties of the transition period in North and South Korea.

\section{(iii) Financial system}

Fundamental problem with reforming North Korea is securing finance for economic transformation. Main trap of modernization of North Korean economy lies in the fact that projects with low or even zero expected returns can be most demanding in terms of required investment. The amounts of required funds will depend on the scheme of restructuring of North Korean economy.

Depending on the priorities chosen for the development of North Korean industries, it is possible to imagine several options for allocating investment resources:

$\checkmark$ complete disposal of existing capacities and creation of new ones on a new technological basis;

$\checkmark$ disposal and partial modernization;

$\checkmark$ modernization and partial disposal;

$\checkmark$ creation of absolutely new facilities on a modern South Korean basis.

Creation in North Korea of a modern banking sector will be another challenge. Experience of Russia and the CIS countries shows that privatization in this sphere can cause large-scale bankruptcies of banks and other financial institutions, emergence of financial pyramid (Ponzi) schemes with serious social consequences for deceived people. 
North Korean overseas banks serving present North Korean leaders as owners of financial resources will be of special interest for new authorities in North Korea.

Resolving problems of these financial sources for new North Korea will demand coordination of actions between the united Korea and the countries that have been the target of Pyongyang's financial activities, that is China (Macau, Hong Kong), Singapore, England, Austria, Switzerland, etc.

The state should decide on the degree of its participation in modernization process and sharing responsibility with national and foreign private business. All this will require considerable fiscal and monetary resources. It is obvious that large-scale modernization of infrastructure and dumping of outdated production facilities, recovery of industrial sites and areas with damaged ecology has to become a priority issue for the government.

Solution of all these tasks will require development of the program of stage-by-stage clearing of depressive branches, with tasks ranged by their urgency. Ranking of projects to be financed will help to avoid misuse of resources to be used to solve creative tasks.

Meanwhile, securing physical survival of people and developing businesses which would satisfy consumer demand will make the government focus attention on legalizing "gray economy". One has to reckon with the existence in the DPRK of illegal economy alongside inefficient legal economy. The main contribution to help this sector of business will be the provision of necessary judicial base, training and retraining of necessary specialists, information support. Financial support for shadow economy (mostly represented by small and medium businesses) will be not so costly in comparison with expenses on infrastructure projects and will bring huge economic and social returns.

\section{(iv) Sectoral development}

Beginning actual market reforms involving structural transformation of North Korean economy will mark the starting point of Korea's unification. Otherwise, economic assistance will under some pretext be withdrawn from implementation of economic and social reforms and will be 
used to strengthen the present regime and to develop its military programs (including nuclear and missile programs) thus aggravating tension on the Korean peninsula and adding pressure on South Korea and regional powers.

It is possible to point out some directions of sectoral development of North Korea after the beginning of reforms.

Some industries will be completely or partially liquidated with no subsequent recovery.

The system of non-market (administrative) distribution of goods and services in its primitive form was reestablished amid the crisis of early 1990's after the former Soviet Union stopped its aid to North Korea following the collapse of the USSR. When North Korea transforms itself into a market economy, rudiments of administrative distribution of goods will be abolished.

At the same time at the first stage of market transformations, the need will remain to render considerable food aid to the poorest strata who constitute a significant part of North Korea's population. A trap here lies in the possibility of misuse or embezzlement of food, medicines and essentials to be distributed, as well as in the possibility that people will see this aid as a charity of local or Pyongyang officials, who will use it to raise political support for themselves.

Many problems will be created by cutting military and related production, as well as by the transformation of heavy industry. Change of political regime and transition to a market economy, as well as the policy of openness, remove need for military production of a former scale. Demand for produce of military and related industries sharply falls. Nuclear and missile production stops altogether.

From Russian experience we see that the transformation of military industry to produce regular consumer and investment goods will most likely be not successful. The difficulties lie not only in poor compatibility of military technologies in their North Korean edition with production of goods for civilian needs, but also in comparative efficiency of creating new facilities and modernization of the existing ones.

However, the main challenge facing military industry and related enterprises lies in their social role. In the former USSR about $70 \%$ of all mining and manufacturing industries were directly or indirectly involved in military production. In North Korea their share is even higher and exceeds 
$80 \%$. Respectively, reforms will result in closing down most of military industry enterprises and in a sharp surge of unemployment.

It is also necessary to take into account the diverse structure of those people in the North Koreans who will need support thorough special programs. On the one hand, aid has to be targeted on securing the survival of those 30-40\% of North Koreans who live now below the poverty line. On the other hand, special attitude will be needed for those affected by cuts in military production and rejection of songun policy ("the priority to of army needs"). It will be necessary to take into account that these people will lose not only means to support their lives, but also social status and privileges in access to better consumer goods, foodstuffs, medical aid, etc.

Considering that maintaining social and political stability will be the main problem at the initial stage of market reforms in North Korea, development and implementation of targeted social programs will be an important condition for the adaptation of North Korean society to economic and social realities of united Korea.

\section{(v) Infrastructure and basic industries}

Basic industries will be subject to total modernization, as the majority of the enterprises of heavy industry do not correspond to modern technical requirements. However, feasibility of investing billions of dollars in industries such as metallurgy will require special research, considering the fact that existing capacities in South of Korea and China can satisfy rising demand. In case of need, companies like POSCO will be able to find necessary solutions, i.e. by creating small specialized steel works.

Another approach would be necessary for obsolete infrastructure facilities, which need to be renovated at the very first stage of reforms, because without them building new North Korean economy will be impossible. They include power, transport, communication (including cell networks) and other facilities. Now they are in poor or rudimentary (as in the case of mobile communication networks) condition.

Maintenance of automobile roads and railroads in North Korea visibly worsened after the Soviet Union suspended its assistance. As a result, transport industry is not capable to satisfy the requirements of even present-day modest economy of the North, not to mention the requirements 
of future market economy linked to that of South Korea, China and Russia. Railway and automobile transport, communication, port facilities etc. need large-scale reconstruction, as well as construction of water supply facilities for the population. In this sphere the priority task will be to demolish outdated and worn-out facilities, build new and also modernize operating ones. From this point of view, ports of Rajin, Nampo, Chongjin, etc. could become the most likely sites to start modernization.

The risks here arise from the fact that from the very first stage of unification there will be a need for close coordination between Korea, China and Russia of efforts to solve internal problems of North Korea and upgrade its transport system.

Similar problems will arise in relation to modernization of North Korean power industry. There is a number of enterprises in this industry which could be modernized for continue operation under certain conditions. Namely, East Pyongyang heat and power facility, oil refinery in Ungi and some others. For a long-lasting solution the North can count on cooperation with power industry of the Russian Far East, which got considerably stronger in recent years, and also with Russian electric power engineering industry. Already there exist plans to incorporate North Korea into energy projects in the Russian Far East. The main threat is consumers' possible illusion of easy availability of electric power. Post-reform experience of Russia, Ukraine and other CIS countries shows that in the conditions when non-market principles of distributing electric power are abandoned, private consumers and businesses tend to interpret "free access to electric power supply networks" (as well as to gas supply networks) as free not only from administrative limitations but of charge as well.

If finance borrowed from international or South Korean sources is to be used to supply electricity to North Korean consumers at the initial stage of resolving North Korean power supply problem, then the following model could be used: payments by a third party - Russian energy supplier - North Korean consumer. At later stages payments by a third party could be gradually replaced with payments from North Korean consumers.

\section{(vi) Potential of traditional export production}

There are sectors in North Korean economy possessing great potential for modernization and organization of export production. Among them the following could be noted specifically: 
- light industries,

- services sector (restaurants, tourism, gambling industry, etc.),

- fishing,

- ore mining.

Considering specific features of these industries and their comparative ability to respond to consumer needs quickly and flexibly, several options are available to dispose of old facilities and construct new ones, to modernize old facilities and retrain personnel. Some enterprises of light industry (for example, cotton-mill in Sarivon, production capacities in Wonsan) working on the basis of simple technologies but capable to keep costs low can continue their production after small-scale modernization. In parallel, creation of new export production facilities will be necessary.

From the point of view of potential domestic and external demand, seafood production, travel, restaurant and hotel business may be promising. Relevant proposals may interest South Korean consumers and tourists from China and Russia. There is also some potential for developing gambling business. However, in case of the latter there could be a trap of possible criminalization of this business, which can challenge maintenance of law and order and social stability during the transition period.

Creation of new facilities in industries focused on a consumer needs can be supplemented with modernization of existing ones. Unlike those in the heavy industry, they do not rely on sophisticated technologies and can quickly reach international quality standards.

Of special interest are main export industries of North Korea, which include coal mining, rare and non-ferrous metals, uranium production. Here modernization of the existing enterprises (for example, steel works in Chongjin) and construction of new facilities are possible. Both will require large investments in electric power and transport infrastructure in respective areas.

Reforming these enterprises to make them work successfully in market environment will be accompanied by privatization of state-owned enterprises. Administrative and legal aspects of this task will incur additional costs related to developing necessary procedures and exercising training. 
Political and legal aspects will include the issue of allowing South Koreans and foreigners to participate in the privatization of North Korean state property. Here reformers will face another trap: these eneterprises are directly linked to shadow economy, which is formally illegal but functioning, as well as to individual business operations of North Koreans.

The trap is the fact that legitimization of local business and arrival of South Korean investors can extinguish sprouts of private North Korean business. Avoiding the risks of infringement of interests of the North Korean while raising both production volumes and standards of quality will become one of the most serious challenges in reforming North of Korea. Measured and balanced decisions will be necessary to encourage legalized shadow business to invest in production facilities and to maintain satisfactory conditions for the workers, including social support conforming to minimal requirements of modern society.

\section{(vii) New types of business focused on export}

A model of export-orientated modernized North Korean economy is the only possible basis for accelerated development of the North in the conditions of mass poverty of the population and low consumer demand. Along with the above-noted opportunities for existing industries there are also new opportunities for export-orientated development in all sectors of North Korean economy.

South Korea has valuable experience of production in North Korean Kaesong Industrial Zone. Creation of 10 to 15 similar zones in Pyongyang and other large cities on the territory of the North could produce rather big effect at small cost. Additionally, they can solve the problem of unemployment and improve the quality of North Korean labor resources during the initial stage of market modernization.

Another version of a special zone is represented by Rason zone. Existing port facilities were built by the USSR to deliver supplies to Vietnam during the Vietnam war, and its transport and hotel infrastructure could bring fruits during the initial stage of modernization. Similar zones could be created in Sinuiju (with focus on China), Nampo (focus on South Korea and ASEAN countries), etc. 
While there is a possibility to develop export potential of the industries already existing in the DPRK, only new businesses created with the participation of South Korean and foreign capital can play a role of perspective drivers capable to bring North Korean goods on foreign markets. Already approved economic zones such as Kaesong and Rason could become the basis for new economic policy towards the outside world after transition of North Korea to market economy and its opening to the outside world. Subsequently creation of new businesses could gradually extend to other regions.

At the same time implementation of such projects may contain another trap, which lies in the relations between investors and North Korean administration within "unification economy", i.e. in the process of creating mechanisms and institutes to serve integration of new North Korean economy into economy of South Korea. Businesses of this new economy in Northern Korea will certainly rely on local education, professional training, health care and law enforcement systems, public administration, water supply and power supply networks etc., which do not conform to modern requirements at all.

Formation of new modern industry in the North may rely on such tools as providing housing to workers on a long-term basis, training programs for workers, export orientation of production. In case of North Korea, exports will be targeted not on U.S. and Japanese markets, as it was in the case of South Korea, but on South Korea, China, Russia, ASEAN, etc.

Creation of new system of cell phone networks with the participation of South Korean and Chinese companies can start with modernizing the limited network developed by an Egyptian company.

Previous attempts to modernize communications in North Korea did not yield result because of political and information restrictions.

A similar situation occurred in the process of German unification when industrial facilities in East Germany were nearly completely replaced with new ones to achieve the desired quality standards. That was done in spite of the fact that former German Democratic Republic (East Germany) was the most advanced country in the communist bloc in terms of level of technology, whereas Democratic People's Republic of Korea is one of the least developed ones. 
Experience of countries of Eastern Europe, Russia and the CIS countries shows that only foreign capital can perform the role of modernizer of industries. For example, most successful examples of production of passenger cars and commercial vehicles in Russia involved local plants built by South Korean, American, German and Japanese companies.

South Korea has its own extensive experience of modernization of the country, and corporations capable of competing successfully on international markets. Taking in into account specific political and social features of North Korea, South Korean government and business in cooperation with international organizations and foreign partners are able to give powerful impulse to systemic reforms and modernization of North Korea.

\section{Foreign and defense policy: relations with China, USA, Japan and Russia}

Unification of Korea can lead to elimination of conflicts and instability on the Korean Peninsula and that conforms to strategic interests of regional powers. At the same time, there are risks related to possible disregard for balance of interests among Korea's neighbors.

China and Russia strongly oppose emergence of a new nuclear power near their borders. They are also anxious about possible new threats here. Given Russian-American political contradictions, heated ChineseAmerican and Chinese-Japanese debates about regional threats to security etc., there is a risk that the united Korea will again turn into a "buffer" state between Russia and China, on the one hand, and the USA and their allies on the other. In this case, there would be actual diplomatic trap. Developments will be pernicious from all points of view: for the development of the United Korea, for regional security and economic integration in Northeast Asia, for implementation of projects of national development. In the end, that would bring back the atmosphere of "cold war" to this region.

It should be noted that the text of the UN Security Council resolution No. 2270 of March 2, 2016 on nuclear missile tests by the DPRK was prepared through US-China consultations. Thus, we have various frameworks for dialogue on problems of the Korean Peninsula, including 
consultations by Washington with Seoul and Tokyo, and an exchange of opinions between Beijing and Moscow.

It reveals contours of an inclusive constructive dialogue between regional powers about the future of the Korean Peninsula, including the unification of Korea. It makes obvious the need to intensify consultations on ways to secure peace and cooperation on the Korean Peninsula, to achieve consensus taking into account strategic priorities of the Korean people and reasonable interests of regional powers.

At the same time, diplomatic activity has to consider existing threats and traps.

Trap No. 1: The issue of nuclear weapons. Leading regional powers (the USA, China, Japan, and Russia) expect from the united Korea full elimination of North Korean nuclear potential. Seoul officially agrees with this approach.

At the same time, there is an opinion among South Korean intellectuals that the South should use North Korean nuclear missile weapons for strengthening Korea's international prestige and national security. If such a scenario is realized, it will invite strong counteraction from all regional powers. Seoul can find itself in the position of a new pariah state with big negative economic consequences.

Trap No. 2: Army. Unification of Korea requires sharp reduction of the size of both North Korean and South Korean army. Refusal to quickly reduce military might of the united Korea (as well as refusal to resolve nuclear issues) will cause tensions in its relations with neighbors. However, fast disarmament will create new security concerns for united Korea, including the factor of the so-called "Chinese threat".

There is also another important question in connection with North Korean nuclear and missile programs, that is the issue of expanding capabilities of antimissile defense in Japan and South Korea. Tokyo began negotiations with the USA on the deployment of missile defense systems in Japan since 1998, after North Korea launched a ballistic missile, which flew over the territory of Japan. In 2004 practical steps took place, when first components of land-based missile defense system deployed near Tokyo. Now four missile defense systems are stationed in Japan, and the deployment of two more systems planned for next several years. 
On the other hand, plans to deploy missile defense systems in South Korea are still in the stage of discussion. The issue in question is the U.S. THAAD antimissile complex (Terminal High-Altitude Area Defense). Under various pressures from the USA and China South Korean leaders so far have been avoiding a final decision on the issue. The problem of military imbalances can complicate political situation related to unification of Korea.

Trap No. 3: Relations with China. First, united Korea should settle the problem of delimitation of its border with China. Therefore, it is important for Seoul to start preliminary studies of various options of resolving territorial problems with China (Pektusan, etc.) at the expert level. Otherwise, relations with China may worsen.

Secondly, there is an unresolved problem of North Korea's debt to Beijing. Considering that the People's Republic of China accounts for $90 \%$ of the DPRK's foreign trade, unresolved problems in relations with China can complicate modernization of North Korean economy. Therefore, settlement of all mutual claims by China and Korea will be an important task.

Thirdly, there is a question of a possible flow of North Korean refugees not only to the South, but also to China. There would be a need to ensure coordination of migration policy between united Korea and the PRC.

Trap No. 4: Economic integration in Northeast Asia. On the one hand, elimination of threats to security in the region as a result of Korean unification creates great opportunities for economic integration between China, Korea and Japan. On the other hand, Seoul's attention will switch from integration in Northeast Asia to problems of reforming the North. While solving this problem, Korea will face interest of private and public companies of the neighboring countries, i.e. of Russia and especially China to North Korean resources. The mechanism of tripartite negotiations between the three countries on future joint modernization of North Korea, including coordination and division of spheres of responsibility with respect to providing assistance could become the basis for creating civilized competitive environment in Korean export-oriented mining industries.

Trap No. 5: Relations with Russia. Russia will support unification of Korea. However, there will perhaps be fears in Russia (especially if the relations with the USA remain tense) that US military facilities will move closer to Russian border as a result of unification. 
It is important to hold preventive consultations to avoid this negative scenario.

After adoption of UNSC Resolution No. 2270 the problem of the Korean Peninsula was discussed at the 2nd round of regular Russia-China Dialogue on Security in Northeast Asia, which took place in Moscow on March 4, 2016. The parties "confirmed the need for strict implementation of the UNSC Resolution No. 2270". At the same time, the Russian Federation and the People's Republic of China noted "negative influence of plans for deployment of the US THAAD missile defense installations in the Republic of Korea on military-political situation in Northeast Asia. Inadmissibility of sliding down to confrontation and arms race in the region was noted".

Approval by UNSC of a strong resolution condemning actions of North Korean regime showed ability of regional powers to agree on coordinated decisions.

\section{Conclusions}

It is possible to note several stages of formation of market economy, justice and democracy in North Korea.

The initial stage - ensuring social stability and eradication of poverty.

The following stage - active formation of market mechanisms and institutes in the North as preparation for unification.

The third stage of changes can have the purpose to begin direct integration of North Korea into economic, social and political life of the South.

The final stage - development of northern regions of re-united Korea

Each stage will require different amount of financial resources, different legislative, economic and social policy.

The main challenges to political reform seem to be the following ones: 
If the WPK and the Kim clan remain in power, they will certainly sabotage and create strategic risks to unification process.

> However, banning and extinguishing them will create vacuum of political power, filling which will require a reasoned, measured policy of gradual step by step stabilization of the North.

> Risk of the population of the North violently opposing the ousting of the Kim clan could materialize in the only case if the Kim clan or the WPK manage to retain their place in political life. In case of their complete retirement from political life, the probability that the population, having lost old leaders, will rise to defend their power and ideology, is practically equal to zero.

Here Russian experience can be more useful than the experience of transition to capitalism in China (where we have different ratio of urban population and economic structure, different scale and political role of the country) or in East Germany where transition occurred in the conditions of fast unification of the country (within one year after the collapse of communist regime).

Though experience of transformation in Russia and some other countries of the CIS and Eastern Europe can be instructive, reforming of North Korean society and unification of Korea is a completely unique case.

The unique nature of North Korean way to market economy and opening of the country lies in the fact that it will be the transformation of an unprecedentedly closed society; that the Korean elites will have to simultaneously search for compromises between social stability and economic efficiency, between openness and the rule of law, between democracy and the sustainability of political institutions, while engaging themselves in a dialogue on internal and external problems with leading regional powers. 
Research Publication

\title{
The Korean Unification: Traps and Challenges
}

\author{
Editors \\ Mikheev Vasilii \\ Fedorovsky Aleksandr
}

Research Report

Подписано в печать 29.06.2016.

Формат $170 \times 240$. Печать офсетная.

Объем 3.75 п.л., 1.41 а.л. Тираж 50 экз. Заказ № 23/2016

Издательство ИМЭМО РАН

Адрес: 117997, Москва, Профсоюзная ул., 23 